\title{
A SOCIOLOGIA DA RELIGIÃO EM PIERRE BOURDIEU: UM EXAME HEURÍSTICO AOS LIMITES DA FÉ E DO JURÍDICO
}

\author{
GLAUCO BARREIRA MAGALHÃES FILHO ${ }^{1}$ \\ ROGÉRIO DA SILVA E SOUZA ${ }^{2}$
}

\begin{abstract}
Resumo:
O presente artigo trata das categorias através das quais Pierre Bourdieu considerou o fenômeno religioso, procura ressaltar as suas contribuições à sociologia da religião, bem como salienta as semelhanças e distinções existentes entre a sua perspectiva e a perspectiva weberiana. A metodologia quanto à abordagem é livre exploratória e do tipo bibliográfica com referência ao pensamento de Pierre Bourdieu. É destacada a tipologia aceita por ele para identificar os atores religiosos e suas ações, bem como as homologias estruturais e funcionais existentes entre os fenômenos religioso, jurídico e econômico. A análise objetiva destacar tanto o potencial heurístico como os limites da sociologia da religião e sua legitimação esboçada por Bourdieu em face da discussão jurídica a respeito, com alguma expressão da realidade latino-americana.
\end{abstract}

Palavras-Chaves: religião, simbólico, campo, mercado religioso, habitus

\section{Abstract:}

This article deals with the categories through which Pierre Bourdieu considered the religious phenomenon and seeks to highlight his contributions to the sociology of religion, as well as the similarities and distinctions between his perspective and the Weberian perspective. The methodology regarding the approach is free of exploratory and bibliographic type with reference to the thought of Pierre Bourdieu. It put emphasis on the typology accepted by him to identify the religious actors and their actions, as well as the structural and functional homologies existing between the religious, legal and economic phenomena. The analysis aims to show both the heuristic potential and the limits of the sociology of religion and its legitimation outlined by Bourdieu in the face of the legal discussion about it, with some expression of the Latin American reality.

Keywords: religion, symbolic, field, religious market, habitus

DOI: $10.7764 /$ RLDR.9.118

\footnotetext{
${ }^{1}$ Mestre em Direito Público pela Universidade Federal do Ceará (UFC), Doutor em Sociologia (UFC), Livre Docente em Filosofia (UVA), membro do NERPO (Núcleo de Estudos de Religião, Política e Cultura) e Professor da disciplina Estudos do Imaginário Jurídico do Programa de Pós-Graduação em Direito da UFC.

2 Doutor em Direito pela Universidade Federal do Ceará (UFC). Mestre em Direito Constitucional pela Universidade de Fortaleza (UNIFOR). Advogado pela Seccional da OAB/Ceará. Professor do Centro Universitário UNIFAMETRO. Em-mail: rogeriojur@hotmail.com
} 
Glauco Barreira Magalhães Filho \& Rogério Da Silva E Souza: A sociologia da religião em Pierre Bourdieu: Um exame heurístico aos limites da fé e do jurídico.

\section{INTRODUÇÃO}

Pierre Bourdieu foi um sociólogo que se dedicou a estudar as mais variadas manifestações da vida social. Embora não ficasse conhecido como um sociólogo da religião, ele também deixou sua contribuição nessa área, sugerindo, inclusive, novas categorias de elevado valor heurístico.

Bourdieu aceitou a tese weberiana segundo a qual os protagonistas da ação religiosa são o profeta, o feiticeiro e o sacerdote, mas destacou também a importância dos leigos. Segundo Bourdieu, o elevado grau de abstração dos chamados tipos-ideais levou Weber a fazer uma longa enumeração de exceções, tornando, assim, as suas definições universais muito pobres.

Ele sugeriu que os atores do mundo religioso fossem vistos não em categorias abstratas isoladas, mas, sim, dentro de uma lógica de interações. Essa lógica complexa, pode ser observada na realidade latino-americana em sua dimensão dos poderios de classes e de compadrios.

Bourdieu, entretanto, transcendeu os limites de pesquisa do chamado interacionismo simbólico, pois entendeu que as interações deveriam ser examinadas mais entre posições dentro do campo religioso do que no plano das relações intersubjetivas. Assim, dentro de um sistema de relações objetivas, seriam ressaltadas as estruturas das interações, e não as meras questões psicológicas a elas inerentes.

O conjunto de relações que os agentes religiosos mantêm entre si e com os leigos constitui o campo religioso. Nesse campo, há produtores (agentes religiosos especializados) e consumidores (leigos), sendo o combate à produção religiosa de auto-consumo dos leigos uma prioridade para os agentes especializados.

Para Bourdieu, na medida em que aumenta a separação entre produtores e consumidores, os produtores ganham mais autonomia e a religião obtém a sua peculiar aparência de sobrenaturalidade, como aduz Pierre Bourdieu:

Em suma, mediante os refinamentos e as complicações com que contribui para o fundo cultural primário, a sistematização sacerdotal tem por efeito manter os leigos à distância (esta é uma das funções de toda teologia esotérica), convencê-los de que esta atividade requer uma 'qualificação especial', 'um dom de graça', inacessível ao comum dos homens, e persuadi-los a desistir da gestão de seus negócios religiosos em favor da 
ISSN 0719-7160

casta dirigente, a única em condições de adquirir a competência necessária para tornar-se um teórico religioso. ${ }^{3}$

Nós examinaremos, nesse artigo, os caracteres que autonomizam o campo religioso, bem como algumas das importantes categorias que Bourdieu utiliza para enfocar o fenômeno da religião, acentuando, enquanto fatos fenomênicos complexos, com isso importância dos direitos no desvendar os aspectos religiosos para o campo jurídico

\section{O CAMPO RELIGIOSO}

Dentro do campo religioso, há relações de transação e relações de concorrência, as quais determinam a sua autonomia. Pierre Bourdieu explica:

As relações de transação que se estabelecem, com base em interesses diferentes, entre os especialistas e os leigos, e as relações de concorrência que opõem os diferentes especialistas no interior do campo religioso, constituem o princípio da dinâmica do campo religioso e também das transformações da ideologia religiosa. ${ }^{4}$

As relações de concorrência interna ao campo religioso se dão entre os sacerdotes, os profetas e os feiticeiros.

O sacerdote é o agente de referência da religião institucionalizada. Ele reproduz o sistema de crenças e ritos sagrados e faz a defesa de uma dada ordem simbólica. É um funcionário da igreja. Depende mais do carisma da instituição e da função que exerce do que do carisma pessoal. Os leigos são os consumidores de seus serviços.

O profeta é um agente religioso que se destaca em situações extraordinárias ou de crise. Às vezes, ele está associado a um grupo marginal que postula uma nova ordem, seja na forma de uma contra-cultura ou de um apelo revolucionário. A legitimidade do profeta está ligada a seu carisma pessoal e, por esse motivo, após a sua morte, o movimento a que ele deu causa tende para a institucionalização, pois os seus discípulos costumam procedimentalizar a transmissão do carisma. A partir daí, surgem sacerdotes que, no futuro, serão objeto de novas contestações proféticas. Esse processo tende a ser cíclico.

${ }^{3}$ BOURDIEU, Pierre. A Economia das Trocas Simbólicas.Trad. Sérgio Miceli et al. $5^{a}$ ed. São Paulo: Editora Perspectiva, 2003, p. 69

${ }^{4}$ BOURDIEU, Pierre. A Economia das Trocas Simbólicas.Trad. Sérgio Miceli et al. $5^{a}$ ed. São Paulo: Editora Perspectiva, 2003, p. 50 
Glauco Barreira Magalhães Filho \& Rogério Da Silva E Souza: A sociologia da religião em Pierre Bourdieu: Um exame heurístico aos limites da fé e do jurídico.

O feiticeiro é um agente religioso autônomo, não institucional e individualista. Faz usos livres e novos de bens simbólicos produzidos pelos sacerdotes e profetas. Age não para manter uma instituição ou reivindicar uma nova ordem simbólica, pois foge as categorias do instituído e do instituinte. O feiticeiro quer apenas atender casuisticamente aos interesses imediatistas de sua clientela.

Pedro A. Ribeiro de Oliveira fala o seguinte acerca do feiticeiro:

Não se vincula nem a uma igreja nem a uma seita, por que seu trabalho religioso se dá em forma de prestação de serviços a quem o procura, sem criar uma comunidade de fiéis, mas uma clientela. Por isso, tende a ser combatido ou desqualificado por profetas e sacerdotes que vêem na magia uma apropriação indevida, ou, pelo menos, manipulação de bens religiosos para finalidades interesseiras e sem fundamentação moral. ${ }^{5}$

A concorrência maior no campo religioso é pelo poder religioso. Esse poder difere de outros (como o político) por suas especificidades. Bourdieu falou o seguinte acerca do poder religioso:

[...] Seu alvo reside no monopólio do exercício legítimo do poder de modificar em bases duradouras e em profundidade a prática e a visão do mundo dos leigos, impondo-lhes e inculcando-lhes um habitus religioso particular, isto é, uma disposição duradoura, generalizada e transferível de agir e de pensar conforme os princípios de uma visão (quase) sistemática do mundo e da existência. ${ }^{6}$

As relações de transação ligam os agentes especializados a grupos ou classes sociais com diferentes demandas (leigos). Assim, as classes dominantes querem legitimação para a sua posição privilegiada, enquanto os dominados querem esperança de libertação ou uma forma de compensação confortante.

A lógica do campo religioso está associada ao cruzamento das relações de concorrência com as relações de transação, ou seja, a dinâmica do campo religioso consiste na competição dos agentes especializados pelo monopólio do atendimento às necessidades dos diferentes leigos, bem como por sua subsistência material.

Para o mundo jurídico, esse fenômeno do campo religioso, há de ser visto nas instituições de poder refletindo os planos da política, da economia, da sociedade, a emergência das classes dos dominantes passam a ser vistas no mundo ocidental, na direção, ainda que velada, das classes sindicais, de partidos políticos, segundo ora a doutrina liberal, ora a intervencionista, como sói

${ }^{5}$ TEIXEIRA FAUSTINO (org.) Sociologia da religião: enfoques teóricos. Petrópolis (RJ): Vozes, 2003, p. 188

${ }^{6}$ BOURDIEU, Pierre. A Economia das Trocas Simbólicas.Trad. Sérgio Miceli et al. $5^{a}$ ed. São Paulo: Editora Perspectiva, 2003, p. 88 
ISSN 0719-7160

acontecer nas instituições classistas - a experiência jurídica, por sua vez, quer integrar limites a esses fenômenos, sob o processo de conferir justiça às diversas liberdades.

\section{NOÇÃO DE RELIGIÃO}

Enquanto Durkheim via a religião como um sistema de ritos, crenças e práticas que se orientam pela noção de sagrado, Bourdieu tratou a religião como uma espécie de linguagem, ou seja, como um sistema simbólico de pensamento e comunicação. ${ }^{7}$

Para Bourdieu, a religião, sendo um estruturado estruturante, é também um veículo de política e de poder. O seu papel principal seria o de produzir sentido, dando ordenação lógica ao mundo natural e social de uma dada sociedade, a fim de integrá-la a um cosmos. Desse modo, a religião faria uma alquimia ideológica, transfigurando relações naturais em relações sobrenaturais. Bourdieu explica:

Neste ponto, Weber está de acordo com Marx ao afirmar que a religião cumpre uma função de conservação da ordem social contribuindo, nos termos de sua própria linguagem, para a legitimação do poder dos dominantes e para a domesticação dos dominados. E, ademais, Weber nos fornece os meios de escapar à alternativa simplista de que são produtos suas análises mais duvidosas, ou seja, à oposição entre a ilusão da autonomia absoluta do discurso mítico ou religioso e a teoria reducionista que torna esse discurso o reflexo direto das estruturas sociais. Procura esclarecer ao máximo o elemento comum ausente no discurso das duas posições opostas e complementares: o trabalho religioso realizado pelos produtores e porta-vozes especializados, investidos do poder, institucional ou não, de responder por meio de um tipo determinado de prática ou discurso a uma categoria particular de necessidades próprias a certos grupos sociais. E, assim, Weber enxerga na gênese histórica de um corpo de agentes especializados o fundamento da autonomia relativa que a tradição marxista confere à religião, sem daí extrair todas as conseqüências e, no mesmo lance, conduz ao núcleo do sistema de produção da ideologia religiosa, a saber, ao princípio mais específico (mas não último) da 'alquimia ideológica' pela qual se opera a transfiguração das relações

\footnotetext{
${ }^{7}$ Neste sentido, vale confrontar a concepção de religião de Otto Maduro: "a religião é um vocábulo situado histórica, geográfica, cultural e demograficamente no seio de uma certa comunidade linguística e que é esta situação particular que dá o sentido ao vocábulo; um sentido rico, mas, no fundo, um sentido complexo, variável, multívoco e confuso". MADURO, Otto. Religião e luta de classes: quadro teórico para a análise de suas inter-relações na América Latina. Trad. Clarêncio Neotti, Ephraim Ferreira Alves. 2.ed. Rio de Janeiro: Vozes, 1983. p.31
} 
Glauco Barreira Magalhães Filho \& Rogério Da Silva E Souza: A sociologia da religião em Pierre Bourdieu: Um exame heurístico aos limites da fé e do jurídico.

sociais em relações sobrenaturais, inscritas na natureza das coisas e, portanto, justificadas ${ }^{8}$.

Os atos simbólicos sempre supõem atos de conhecimento e de reconhecimento, atos cognitivos dos seus destinatários. A troca simbólica só funciona quando as categorias de percepção e de avaliação das partes são idênticas. Desse modo, atos de dominação simbólica são exercidos com a cumplicidade dos dominados. ${ }^{9}$ A transfiguração de uma relação é criação de todo o grupo, pois a alquimia só funciona se for sustentada por toda a estrutura social.

A violência simbólica só produz a transfiguração das relações de dominação e de submissão em relações afetivas se houver o reconhecimento. Só então pode haver a transformação do poder em carisma adequado a suscitar um encantamento afetivo. Bourdieu observa o seguinte:

A alquimia simbólica, tal como acabo de descrevê-la, produz, em proveito daquele que cumpre com esses atos de eufemismo, de transfiguração, de conformação, um capital de reconhecimento que the permite ter efeitos simbólicos. É o que chamo de capital simbólico, atribuindo assim um sentido rigoroso ao que Max Weber designava pela palavra carisma. ${ }^{10}$

Para Bourdieu, explica Pedro A. Ribeiro de Oliveira, a religião é uma força estruturante da sociedade, em virtude de transformar o "assim é" em "assim deve ser" ou em "assim não pode ser $^{\prime 11}$. Desse modo, as teodicéias (justificativas filosóficas do modo como Deus se relaciona com o mundo e com os homens) podem ser compreendidas como sociodicéias que justificam as desigualdades e os privilégios, bem como legitimam as instituições. Isso, todavia, não significa que a religião serve apenas aos interesses da classe dominante. A classe dominada também busca na religião a esperança de libertar-se da opressão. Numa posição intermediaria, há os religiosos que condenam as injustiças sociais, mas aguardam uma intervenção divina futura para dar ordem as coisas.

\footnotetext{
8 BOURDIEU, Pierre. A Economia das Trocas Simbólicas.Trad. Sérgio Miceli et al. $5^{\mathrm{a}}$ ed. São Paulo: Editora Perspectiva, 2003, p. 32-33

${ }^{9}$ A despeito da segmentação religiosa, Pierre Bourdier vai advertir de uma dominação cultural além da religião, senão veja-se: "A cultura é um instrumento de legitimação e de dominação. Weber dizia da religião que ela dá aos dominantes uma teodiceia de seus próprios privilégios. Prefiro falar de sociodiceia: ela oferece uma legitimação da ordem social tal como ela é. Mas não é só isso. Acultura sucede à religião com funções perfeitamente semelhantes: dá aos dominantes a sensação de estarem fundamentados em sua dominação, e isso na escala de uma sociedade nacional, mas também na escala da sociedade mundial". BOURDIEU, Pierre. Sobre o Estado: Cursos no Collège de France (1989-92). Trad. Rosa Freire d'Aguiar. 3a. reimp. São Paulo: Companhia das Letras, 2014. p. 220.

10 BOURDIEU, Pierre. Razões Práticas: Sobre a teoria da ação. Trad. Mariza Côrrea. $3^{a}$ ed. Campinas, SP: Papirus, 2001, p. 170

${ }^{11}$ TEIXEIRA FAUSTINO (org.) Sociologia da religião: enfoques teóricos. Petrópolis (RJ): Vozes, 2003, p. 179-180
} 


\section{ISSN 0719-7160}

A eficácia simbólica da religião, uma função eminentemente política, dependerá da incorporação de esquemas de pensamento que se inscreverão nos hábitos. A eficácia simbólica das práticas religiosas depende da crença nessa mesma eficácia. A ideologia do carisma, por exemplo, é o poder simbólico conferido pela crença no próprio poder simbólico.

De acordo com Bourdieu, a religião procura absolutizar o relativo e legitimar o arbitrário, ocultando interesses não religiosos (como os de ordem política e econômica) sob a máscara de interesses religiosos. É, então, que opera o princípio do efeito de consagração, que cumpre a função de conhecimento-desconhecimento da ideologia e prática religiosa.

O fato, porém, de existirem interesses não religiosos mascarados de religiosos não significa que a religião pode ser algo simplesmente imposto ou colocado de qualquer forma, pois ela atende a uma demanda específica. O trabalho religioso consiste na produção de crenças, práticas e discursos que, sob o manto do sagrado, satisfazem a uma necessidade de expressão de um grupo ou classe social.

Para Bourdieu, a igreja contribui para a manutenção da ordem política, reforçando as suas divisões, ou seja, naturalizando-as. Podem, porém, existir tempos em que há o enfraquecimento ou declínio das tradições ou sistemas simbólicos que forneciam os princípios da visão do mundo e da orientação da vida. Nesses períodos de crise, surgem messias e profetas.

Bourdieu critica a representação weberiana do carisma como algo associado à peculiaridade de um indivíduo singular excepcional. O profeta não seria tanto um homem "extraordinário", mas o homem das situações extraordinárias. Os profetas hebreus, por exemplo, apareciam normalmente em momentos de guerras.

Os profetas seriam os inventores do futuro escatológico, pois a crise da linguagem ordinária exige ou autoriza a linguagem de crise e a crítica da linguagem ordinária. Para Bourdieu, o estudo do carisma deveria examinar o seguinte:

As características sociologicamente pertinentes de uma biografia singular que tornam um determinado indivíduo socialmente predisposto a sentir e a expressar com uma força e uma coerência particulares certas disposições 
Glauco Barreira Magalhães Filho \& Rogério Da Silva E Souza: A sociologia da religião em Pierre Bourdieu: Um exame heurístico aos limites da fé e do jurídico.

éticas ou políticas já presentes, em estado implícito, em todos os membros da classe ou do grupo de seus destinatários. ${ }^{12}$

A religião, portanto, seguiria uma dinâmica social, tendo poder de legitimação e de subversão da ordem, conservando e também recriando referencias simbólicos.

Os direitos, não querem enunciar um conceito ou um sentido para a religião, mas quer admitir que as instituições religiosas são plurais e, para tanto, o fracionamento dessas instituições, ora majoritárias, ora minoritárias, é o que acaba por conformar o endereçamento dos dominantes sobre os dominados. No caso latino-americano a emergência de instituições religiosas uma nova roupagem do conceito institucional religioso, exsurge com a teologia do domínio e a lógica da prosperidade, e por sua vez, constrói novos problemas às lides jurídicas, a exemplo da influência abusiva dessas instituições nas políticas comunitárias, ${ }^{13}$ com forte manifestação no partidarismo político, não raro, oferecendo aos direitos administrativos, eleitorais, constitucionais standards jurídicos a solucionar. ${ }^{14}$

\section{O MERCADO RELIGIOSO}

O campo religioso é explicado por Bourdieu também na figura do mercado, pois sua estrutura é representada como um conjunto de relações objetivas entre a demanda religiosa (os interesses religiosos dos diferentes grupos ou classe de leigos) e a oferta religiosa (serviços religiosos de tendência ortodoxa ou herética). Dessa estrutura depende o capital religioso.

Bourdieu toma a noção de capital, que está ligada originalmente à abordagem econômica, e amplia o seu uso, reconhecendo as características (levadas a áreas não econômicas por analogia) que fazem dela um conceito heurístico. Essas características ou propriedades reconhecidas do

\footnotetext{
12 BOURDIEU, Pierre. A Economia das Trocas Simbólicas.Trad. Sérgio Miceli et al. $5^{\text {a }}$ ed. São Paulo: Editora Perspectiva, 2003, p. 74

${ }^{13} \mathrm{O}$ problema do abuso do poder religioso é palavra de instância de validade normativa de legitimidade, via de regra, a autoridade religiosa arregimenta o seu sectarismo que a persegue voluntariamente e consciente de suas ações; por exceção essa mesma autoridade arbitra do poder, através de mecanismos linguísticos e institucionais que deturpam a condução de seus fins.

${ }^{14}$ Jesús González Pérez assinala: "hoy vivimos en Occidente 'una crisis de valores morales es porque, en el fondo, vivimos una crisis de los valores que el cristianismo representa'y 'esta crisis enlaza directamente con el sentimiento de obrigatoriedad en nuestra sociedad y paralelamente, la inflación de la actividad reivindicatoria', o 'dicho de otra forma, la crisis actual repercute positivamente a favor de los derechos y negativamente a favor de los deberes'. 'En una sociedad que valora por encima de todo la productividad y la eficacia, la riqueza material y el individualismo posesivo". PÉREZ, Jesús González. La ética em la Administración pública. 2a. ed. Madrid: Civitas, 2000. (Colección Cuadernos Civitas). p.22.
} 


\section{ISSN 0719-7160}

capital são: acumulação por meio de operações de investimentos, transmissão pela herança e possibilidade de gerar lucros segundo a oportunidade que o seu detentor tiver de operar as aplicações mais rentáveis. Ao longo da ampla obra de Bourdieu, são mencionados o capital econômico, o capital cultural, o capital social e o capital simbólico. No caso, o capital religioso seria uma espécie de capital simbólico. ${ }^{15}$ Patrice Bonnewitz, estudiosa do pensamento de Bourdieu, explica:

O capital simbólico, que corresponde ao conjunto dos rituais (como as boas maneiras ou o protocolo) ligados à honra e ao reconhecimento. Afinal, apenas o crédito e a autoridade conferem a um agente o reconhecimento e a posse das três outras formas de capital. Ele permite compreender que as múltiplas manifestações do código de honra e das regras de boa conduta não são apenas exigências do controle social, mas são constitutivas de vantagens sociais com consequências efetivas. ${ }^{16}$

O capital simbólico é uma propriedade que se torna eficiente como uma verdadeira força mágica ao ser percebida pelos agentes sociais dotados das categorias de percepção e de avaliação que permitem reconhecê-la. Trata-se de uma propriedade que, por responder às "expectativas coletivas", exerce uma espécie de ação à distância, independentemente do contato físico.

No campo da religião, o capital simbólico determina a natureza, a forma e a força das estratégias que as instâncias religiosas podem colocar a serviço da satisfação dos seus interesses. Isso é passível de ser percebido na luta pelo monopólio do exercício legítimo do poder religioso sobre os leigos, assim como pela gestão dos bens de salvação, o que se apresenta nas disputas entre a igreja e o profeta e sua seita.

Entre as formas de capital religioso, encontramos o capital de autoridade propriamente religiosa e o capital de graça institucional ou sacramental.

\footnotetext{
15 Para Cornelius Castoriadis: "[...] dizer que os homens buscaram sempre o maior desenvolvimento possível das forças produtivas e que só encontraram como obstáculo o estado da técnica; ou que as sociedades foram sempre "objetivamente" dominadas por esta tendência, e organizadas em função dela, é extrapolar abusivamente o conjunto da história, as motivações e os valores, o movimento e a organização da sociedade atual - mais exatamente, da metade capitalista da sociedade atual. A ideia de que o sentido da vida consistiria na acumulação e na conservação de riquezas seria uma loucura para os índios Kwakiutl, que acumulam riquezas para poder destruí-las; a ideia de procurar poder e o comando seria loucura para os índios Zuni entre os quais, para fazer de alguém um chefe da tribo, é preciso espancá-lo até que aceite." CASTORIADIS, Cornélius. A instituição imaginária da sociedade. 2a. ed. Trad. Guy Reynoud. Rio de Janeiro: Paz e Terra, 1982.p.38 16 BONNEWITZ, Patrice. Primeiras linhas sobre a Sociologia de P. Bourdieu. Trad. Lucy Magalhães. Petrópolis, RJ: Vozes, 2003, p.54
} 
Glauco Barreira Magalhães Filho \& Rogério Da Silva E Souza: A sociologia da religião em Pierre Bourdieu: Um exame heurístico aos limites da fé e do jurídico.

O capital de autoridade religiosa se define na força material e simbólica através da qual uma instância religiosa mobiliza grupos ou classes, oferecendo-lhes bens e serviços aptos a satisfazer seus interesses religiosos.

Há no capital de autoridade religiosa uma relação circular ou dialética, pois ele é utilizado nas relações de concorrência ao mesmo tempo em que é produto delas. De acordo com Bourdieu, o capital de autoridade religiosa

É a base da harmonia que se observa entre os produtos religiosos oferecidos pelo campo e as demandas dos leigos,e, ao mesmo tempo, constitui a base da homologia entre as posições dos produtores na estrutura do campo e as posições dos consumidores de seus produtos na estrutura das relações de classe. ${ }^{17}$

O capital de graça institucional ou sacramental é algo que a igreja não apenas deseja conquistar, mas também monopolizar o máximo que puder. Esse capital é um objeto de troca com os leigos. Ele determina o controle do acesso aos meios de produção, de reprodução e de distribuição dos bens de salvação, sendo delegado a um corpo de sacerdotes (funcionários intercambiáveis do culto). Esse capital institucional, não depende do carisma pessoal, mas da autoridade da função. Isso dispensa os sacerdotes de uma peleja contínua para conquistar e manter a sua autoridade, assim como protege o caráter sagrado da instituição dos prejuízos decorrentes dos eventuais fracassos pessoais de seus agentes.

A figura do mercado (mercado simbólico) em Bourdieu se materializa na idéia de gestão do depósito de capital religioso, na apresentação do corpo de sacerdotes como produtores de bens de salvação e dos leigos (em oposição aos infiéis e aos heréticos) como consumidores dotados de um mínimo de competência religiosa (habitus religioso) necessária para sentir a necessidade específica de seus produtos.

A luta pelo monopólio do exercício do poder religioso legítimo sobre os leigos e a gestão dos bens de salvação leva a igreja a tentar impedir de maneira mais ou menos rigorosa a entrada no mercado de novas empresas de salvação, bem como da religiosidade individual. Essa luta justifica a tensão entre a igreja e o profeta e sua seita.

A igreja caracteriza-se por apresentar inúmeros traços de uma burocracia. Apesar de surgir em oposição à igreja, a seita, quando se impõe socialmente, tende a tornar-se igreja, pois se torna

${ }_{17}$ BOURDIEU, Pierre. A Economia das Trocas Simbólicas.Trad. Sérgio Miceli et al. $5^{\text {a }}$ ed. São Paulo: Editora Perspectiva, 2003, p. 58 


\section{ISSN 0719-7160}

depositária de uma ortodoxia formalizada em dogmas e preservada por uma hierarquia. Nessa hora, a situação evoca uma nova reforma.

O profeta é um empresário independente de salvação, de cuja atuação pode nascer uma seita. A sua pretensão é propor um novo tipo de produção e distribuição dos bens de salvação, o que acarreta a desvalorização dos antigos. Na falta de suficiente capital inicial, o profeta se legitima pelo carisma pessoal, sendo sua "pessoa" a única caução ou garantia.

Os traços comuns que unem o profeta e o feiticeiro (pequeno empresário) são os fatos de ambos serem empresários independentes (capazes de exercer seu ofício fora de qualquer instituição) e de ambos fazerem oposição ao corpo de sacerdotes.

A autoridade religiosa institucional procura conservar o monopólio de seu poder simbólico através da aptidão para fazer reconhecer aos que dela estão excluídos a legitimidade de sua exclusão, de modo a que não reconheçam a arbitrariedade das decisões institucionais. Também procura neutralizar a contestação profética ou herética que ameaça a própria existência da instituição eclesiástica. Bourdieu explica as estratégias da instituição eclesiásticas:

Assim, quando as relações de força são favoráveis à igreja, a consolidação dessa depende da supressão do profeta (ou da seita) por meio da violência física ou simbólica (excomunhão), a menos que a submissão do profeta (ou do reformador), ou seja, o reconhecimento da legitimidade do monopólio eclesiástico (e da hierarquia que o garante), permita sua anexação pelo processo de canonização (por exemplo, São Francisco de Assis). ${ }^{18}$

Do ponto de vista econômico, Bourdieu observa que a empresa religiosa, embora sendo possuidora de dimensões econômicas, não pode confessar esse fato. O seu funcionamento ocorre em uma negação permanente de sua dimensão econômica. Na verdade, isso faz parte das próprias condições de funcionamento e de êxito da empresa religiosa.

A empresa religiosa só pode se beneficiar de vantagens econômicas na medida em que reproduz as condições de desconhecimento de sua dimensão econômica, isto é, enquanto os agentes continuem a crer, e a fazer crer, que suas ações não têm nenhuma incidência econômica ${ }^{19}$.

${ }_{18}$ BOURDIEU, Pierre. A Economia das Trocas Simbólicas.Trad. Sérgio Miceli et al. $5^{\text {a }}$ ed. São Paulo: Editora Perspectiva, 2003, p. 62

19 BOURDIEU, Pierre. Razões Práticas: Sobre a teoria da ação. Trad. Mariza Côrrea. $3^{a}$ ed. Campinas, SP: Papirus, 2001, p. 191 
Glauco Barreira Magalhães Filho \& Rogério Da Silva E Souza: A sociologia da religião em Pierre Bourdieu: Um exame heurístico aos limites da fé e do jurídico.

A economia dos bens simbólicos apóia-se no recalque ou na censura do interesse econômico (no sentido restrito do termo ${ }^{20}$. Ela é fluida e indeterminada, pois se apóia no tabu da explicitação.

No mundo ocidental, cujo fenômeno se aguça na América Latina a dimensão econômica e organizada no campo religioso prevalece com interesses oligopólios que, ora enriquecem-se com manifesto desvio de finalidade, ora se assenhoram do poder estatal, o que não é legítimo no Estado Democrático de Direito.

Com efeitos, os bens de consumo nem sempre o são materiais, podem sê-lo imateriais ou espirituais; daí que as instituições religiosas podem mercadejar bens imateriais, no sentido de que oferta uma mensagem patrimonial de benefícios espirituais e há procura de tais bens, com o intuito de resguardar esses bens, na experiência de recorrê-los, ainda que se tenha de pagar por esses benefícios. ${ }^{21}$

\section{CRÍTICAS E CONSIDERAÇÕES FINAIS}

Bourdieu, como cientista social responsável, procura exercer controle sobre seus preconceitos, tendo, inclusive, observado que uma verdadeira sociologia da religião só é possível se for acompanhada de uma sociologia científica do campo religioso. Ele lembra que a sociologia da religião não pode servir, por exemplo, para o ex-clérigo acertar as contas com a instituição, pois a raiva, a indignação e a revolta são sinais de interesse negativo e crítico que podem ser confundidos com a atitude científica. ${ }^{22} \mathrm{~A}$ impressão, todavia, que se tem é a de que Bourdieu quer se convencer a si mesmo da veracidade de sua atitude científica pessoal, pois a sua linguagem, as suas comparações e a seleção de seus exemplos evidenciam um juízo negativo acerca da religião, sendo

\footnotetext{
20 BOURDIEU, Pierre. Razões Práticas: Sobre a teoria da ação. Trad. Mariza Côrrea. $3^{a}$ ed. Campinas, SP: Papirus, 2001, p. 193

${ }^{21}$ Atualmente, no contexto mundial da pandemia da Covid-19, especialmente no Brasil, não faltaram igrejas que oferecessem benefícios espirituais, como a água milagrosa a curar da enfermidade, além disso, discute-se abertura e templos, para cultos e liturgias, como atividade essencial em meio à pandemia, independentemente, do risco de contágio no âmbito das igrejas. PIRES, Breiller. Igrejas desafiam recomendação de suspender missas e cultos diante da pandemia do coronavírus. El país. São Paulo, 19 mar. 2020. Disponível em: https://brasil.elpais.com/brasil/2020-03-20/igrejas-desafiam-recomendacao-desuspender-missas-e-cultos-diante-da-pandemia-do-coronavirus.html . Acesso em: 29 mar. 2020.

22 BOURDIEU, Pierre. Coisas ditas. Trad. Cássia R. da Silveira e Denise Moreno Pegorim. São Paulo: Brasiliense, 2004, p. 108-110
} 


\section{ISSN 0719-7160}

seu modo de falar caracterizado em muitas oportunidades por uma ironia que assinala desprezo pelas instituições religiosas.

Max Weber, quando considerou a influência das crenças no comportamento social, sem questionar as razões mais profundas das próprias crenças, manifestou maior fidelidade ao espírito científico que Bourdieu.

De modo semelhante a Durkheim, Bourdieu parece reduzir a religião a um fenômeno social. Tal conclusão, porém, excede a missão sociológica. Na linha de pensamento perfilhada por Georg Simmel, nós preferimos dizer que cabe ao sociólogo estudar a dimensão social da religião, mas não Ihe compete ajuizar sobre a redução da totalidade da religião a um fenômeno social.

Simmel explica que, dentro do complexo religioso geral, elementos sociais "se fundem organicamente com a disposição religiosa" e que eles podem ser "sociologicamente isolados" 23 . Dentro dessa perspectiva, podemos aceitar a crítica de Julien Freund a Durkheim:

E mais segundo o unilateralismo partidário, acreditava ele poder reduzir, além da moral e da política, a teoria do conhecimento e o espírito da religião a simples fatores sociológicos... Ora, todas estas afirmações e posições são julgamentos de valor que escapam à competência de qualquer ciência. No entanto, Durkheim as revestiu da autoridade da sociologia ${ }^{24}$.

Bourdieu parece ser lacunoso ao não destacar a importância dos leigos como produtores anônimos e coletivos de bens religiosos, pois tende a reduzi-los a condição de consumidores passivos. Nesse aspecto, seria interessante que as pesquisas de Bourdieu fossem complementadas pelas contribuições de Michel de Certeau acerca do papel criativo dos consumidores em sua obra $A$ invenção do cotidiano.

Bourdieu explica a religião institucional como uma estrutura hierárquica que combate o autoconsumo religioso. A sua visão parece tomar o catolicismo como paradigma. É perceptível a omissão quanto à análise do protestantismo clássico com suas doutrinas do sacerdócio universal de todos os crentes, do livre exame das Escrituras e da superação da igreja como mediadora da graça.

${ }_{23}^{23}$ SIMMEL, Georg. Questões fundamentais da sociologia. Trad. Pedro Caldas, Rio de Janeiro: Jorge Zahar Ed. 2006, p.24

${ }^{24}$ FREUND, Julien. Sociologia de Max Weber. Trad. Luís Cláudio de Castro e Costa. $4^{\mathrm{a}}$ ed. Rio de Janeiro: Forense-Universitária, 1987, p.15 
Glauco Barreira Magalhães Filho \& Rogério Da Silva E Souza: A sociologia da religião em Pierre Bourdieu: Um exame heurístico aos limites da fé e do jurídico.

Para Richard Posner, por exemplo, na experiência norte-americana, a liberdade religiosa é uma política de interesse social de custo justificado, isto porque a sociedade promove um controle social que gerencia os comportamentos com a maximização utilitarista de casos particulares, para isso que o Estado a resguarda tanto como maximizadora da utilidade, quanto da riqueza. ${ }^{25}$

Porém, isso não quer dizer que se possa justificar o abuso de poder econômico, com desvio do exercício regular do direito por quem detém legitimidade para decidir sobre a coletividade, no caso, uma instituição eclesiástica, mesmo na esfera privatista. E isto não é decadência da religião do Ocidente nem do Oriente, é que em cada religião repousam verdades da transcendência, mas o seu mau uso, por alguém que lhe determine o pragmatismo pernicioso, conduz a poderios infelizes na ordem social. É o sectarismo que se fez perder no fanatismo terrorista, o desvio de finalidades espirituais para emergir na construção de patrimônios incomensuráveis, dentre outras tantas.

Dentro de nossa apreciação, a importância do simbólico, que não é mero reflexo do real, bem como a idéia de transfiguração foram as mais importantes contribuiç̧̃es de Bourdieu para a sociologia da religião. Por outro lado, foi de grande valor heurístico a compreensão de Bourdieu do campo religioso como um lugar de luta pela definição, isto é, pela delimitação das competências, competência no sentido jurídico do termo ${ }^{26}$.

Provavelmente, a regulação jurídico-econômica da ordem religiosa se faça possível, para o equilíbrio e o verdadeiro papel da religiosidade na vida humana. Certo é que não se conseguirá, de todo, vencer o abuso intersubjetivo nas relações entre instituições religiosas (leia-se sectarismo e liderança religiosa), na medida em que a moeda ali circulada, não raro, não é declarada, mas para esclarecer os sectários e controlar tais abusos, há de se delimitar os atos que desvirtuam as finalidades da instituição religiosa per si, sob o risco de regressar-se a um Estado teocrático desregulado, ainda que de forma velada.

25 POSNER, Richard. Problemas de Filosofia do Direito. Trad. Jefferson Luiz Camargo. Rev. tec. trad. Mariana Mota Prado. São Paulo: Martins Fontes, 2007.

${ }^{26}$ BOURDIEU, Pierre. Coisas ditas. Trad. Cássia R. da Silveira e Denise Moreno Pegorim. São Paulo: Brasiliense, 2004, p. 120 
ISSN 0719-7160

\section{REFERÊNCIAS BIBLIOGRÁFICAS}

BONNEWITZ, Patrice. Primeiras linhas sobre a Sociologia de P. Bourdieu. Trad. Lucy Magalhães. Petrópolis, RJ: Vozes, 2003.

CASTORIADIS, Cornélius. A instituição imaginária da sociedade. 2a. ed. Trad. Guy Reynoud. Rio de Janeiro: Paz e Terra, 1982.

CERTEAU, Michel de. A Invenção do Cotidiano: 1. Artes de fazer. Trad. Ephraim Ferreira Alves. $8^{\mathrm{a}}$ ed. Petrópolis, RJ: Vozes, 1994.

BOURDIEU, Pierre. Razões Práticas: Sobre a teoria da ação. Trad. Mariza Côrrea. 3a. ed. Campinas, SP: Papirus, 2001.

BOURDIEU, Pierre. A Economia das Trocas Simbólicas. Trad. Sérgio Miceli et al. 5a. ed. São Paulo: Editora Perspectiva, 2003.

BOURDIEU, Pierre. Coisas ditas. Trad. Cássia R. da Silveira e Denise Moreno Pegorim. São Paulo: Brasiliense, 2004.

BOURDIEU, Pierre. Sobre o Estado: Cursos no Collège de France (1989-92). Trad. Rosa Freire d'Aguiar. 3a. reimp. São Paulo: Companhia das Letras, 2014.

FREUND, Julien. Sociologia de Max Weber. Trad. Luís Cláudio de Castro e Costa. 4a. ed. Rio de Janeiro: Forense-Universitária, 1987.

MADURO, Otto. Religião e luta de classes: quadro teórico para a análise de suas inter-relações na América Latina. Trad. Clarêncio Neotti, Ephraim Ferreira Alves. 2a.ed. Rio de Janeiro: Vozes, 1983.

PÉREZ, Jesús González. La ética em la Administración pública. 2a. ed. Madrid: Civitas, 2000. (Colección Cuadernos Civitas).

PIRES, Breiller. Igrejas desafiam recomendação de suspender missas e cultos diante da pandemia do coronavírus. El país. São Paulo, 19 mar. 2020. Disponível em: https://brasil.elpais.com/brasil/2020-03-20/igrejas-desafiam-recomendacao-de-susp-endermissas-e-cultos-diante-da-pandemia-do-coronavirus.html . Acesso em: 29 mar. 2020. 
Glauco Barreira Magalhães Filho \& Rogério Da Silva E Souza: A sociologia da religião em Pierre Bourdieu: Um exame heurístico aos limites da fé e do jurídico.

POSNER, Richard. Problemas de Filosofia do Direito. Trad. Jefferson Luiz Camargo. Rev. tec. trad. Mariana Mota Prado. São Paulo: Martins Fontes, 2007. POSNER, Richard. Problemas de Filosofia do Direito. Trad. Jefferson Luiz Camargo. Rev. tec. trad. Mariana Mota Prado. São Paulo: Martins Fontes, 2007.

SIMMEL, Georg. Questões fundamentais da sociologia. Trad. Pedro Caldas, Rio de Janeiro: Jorge Zahar Ed. 2006

TEIXEIRA FAUSTINO (org.) Sociologia da religião: enfoques teóricos. Petrópolis (RJ): Vozes, 2003 